\title{
Perlindungan Hukum Terhadap Tersangka Pada Tahap Pemeriksaan Oleh Polri Menurut Kitab Undang-Undang Hukum Acara Pidana
}

\author{
Agus I Supriyanto*) \\ ${ }^{*}$ Dosen Fakultas Hukum Universitas Islam Lamongan
}

\begin{abstract}
Abstrak
Peraturan yang menjadi dasar bagi pelaksanaan hukum acara pidana adalah Undang-Undang Republik Indonesia Nomor 8 Tahun 1981, Lembaran Negara (LN) Nomor 3209 tentang Hukum Acara Pidana yang diundangkan 31 Desember 1981, yang sering disebut Kitab Undang-Undang Hukum Acara Pidana (KUHAP)..

Didalam materi pasal-pasalnya tercermin adanya perlindungan Hak Asasi Manusia (HAM). Dan salah satu asas yang dianut dikenal dengan istilah 'asas praduga tak bersalah'yaitu tidak seorangpun boleh ditangkap, ditahan dan diasingkan secara sewenang-wenang dianggap bersalah melakukan tindakan pidana sebelum ia dinyatakan bersalah oleh Pengadilan melalui suatu putusan yang mempunyai kekuatan hukum pasti (in kracht van gewisjde).
\end{abstract}

\section{Kata Kunci :Perlindungan Hukum, Tersangka, Tahap pemeriksaan.}

\section{Pendahuluan}

Negara Republik Indonesia adalah negara yang berdasarkan atas hukum (rechtsstaat) dan tak berdasarkan atas kekuasaan belaka (machtsstaat). Hal ini mengandung pengertian pokok negara hukum, bahwa kekuasaan negara dibatasi oleh dan juga berdasarkan atas hukum, jadi bukanlah berdasarkan atas kekuasan semata-mata. Pengertian ini dapat kita lihat dalam penjelasan UUD 1945 (tercantum dalam sistem pemerintah Negara Kesatuan Republik Indonesia).

Pasal 27 ayat (1) UUD 1945 menjamin segala warga negara bersamaan kedudukannya didalam hukum pemerintahan dan wajib menjunjung hukum dan pemerintahan itu dengan tidak ada kecualinya.

Konsep negara berdasarkan hukum di Indonesia mengandung prinsip-prinsip yang mencakup unsur-unsur perlindungan Hak Asasi Manusia (HAM), pemisahan kekuasaan, setiap tindakan pemerintahan harus didasarkan pada peraturan Undang-Undang dan adanya peradilan administrasi yang berdiri sendiri (Moh Kusnardi dan Harmaily Ibrahim, 1983:156).

Negara Republik Indonesia menjunjung tinggi Hak Asasi Manusia (HAM), penghayatan, pengamalan dan pelaksanaan Hak Asasi Manusia (HAM) dan kewajiban warga negara untuk keadilan tidak boleh diabaikan oleh setiap warga negara, penyelenggara negara, lembaga negara dan lembaga kemasyarakatan di pusat dan di daerah yang perlu terwujud pula dalam dan dengan hukum acara pidana.

Peraturan yang menjadi dasar bagi pelaksanaan hukum acara pidana dalam lingkungan peradilan hukum dan Mahkamah Agung (MA) sebelumnya adalah HetHherziene Inlandsch Reglemen (HIR) Staatsblad Tahun 1941 Nomor 44 yang merupakan hasil karya pemerintah kolonial Belanda.

Kemudian karena tidak sesuai lagi dengan cita-cita hukum nasional dan pembangunan di bidang hukum maka Undang-Undang dan acara pidana tersebut dicabut dan sebagai penggantinya adalah Undang-Undang Republik Indonesia Nomor 8 Tahun 1981, Lembaran Negara (LN) Nomor 3209 tentang Hukum Acara Pidana yang diundangkan 31 Desember 1981, yang sering disebut Kitab Undang-Undang Hukum Acara Pidana (KUHAP).

Kitab Undang-Undang Hukum Acara Pidana (KUHAP) mempunyai beberapa kelebihan antara lain ketentuan mengenai bantuan hukum pada semua tingkat pemeriksaan, hak memberi ganti rugi, menjunjung tinggi Hak Asasi Manusia (HAM) dan menjamin kedudukan yang sama bagi semua warga negara didalam hukum.

Didalam materi pasal-pasalnya tercermin adanya perlindungan Hak Asasi Manusia (HAM), demikian pula dengan asas yang dianutnya. Dan salah satu asas yang dianut dikenal dengan istilah 'asas praduga tak bersalah' yang diatur dalam pasal 8 Undang-Undang Nomor 14 Tahun 1970 
(Undang-Undang Pokok Kekuasaan Kehakiman) dan juga diatur dalam penjelasan umum butir 3 Kitab Undang-Undang Hukum Acara Pidana (KUHAP).

Berdasarkan asas tersebut, tidak seorangpun boleh ditangkap, ditahan dan diasingkan secara sewenang-wenang dianggap bersalah melakukan tindakan pidana sebelum ia dinyatakan bersalah oleh Pengadilan melalui suatu putusan yang mempunyai kekuatan hukum pasti (in kracht van gewisjde).

Kenyataannya asas praduga tak bersalah ini kadangkala tidak berlaku sesuai dengan teori. Polisi, penuntut umum atau birokrat yang tidak jarang melanggar asas tersebut, muncul fenomena penyidikan kejahatan diwarnai penganiayaan. Polisi sudah memvonis tersangka melakukan kejahatan dan harus dihukum. Tersangka dipaksa mengakui kejahatannya. Bila tidak, ia disiksa sampai mengakui kejahatan yang dituduhkan.

Berdasarkan latarbelakang pemikiran sebagaimana tersebut diatas, berikut ini akan dicoba dibahas beberapa persoalan sebagai berikut:

1 Bagaimanakah hak-hak tersangka dalam pemeriksaan pendahuluan?

2 Bagaimanakah pelaksanaan jaminan perlindungan hukum terhadap tersangka dalam pemeriksaan pendahuluan?

\section{Pengertian Hak, Perlindungan Hukum dan Perkara Pidana}

Dalam buku Inleiding tot de studie van Het Nederlandsche Recht oleh Van Apeldom mengatakan bahwa :

"Hak adalah hukum yang dihubungkan dengan seorang manusia atau subjek hukum tertentu menjelma menjadi suatu kekuasaan dan suatu hak timbul apabila hukum mulai bergerak". (CST. Kansil, 1989:119)

Perlindungan hukum adalah hak yang dimiliki seorang manusia atau subyek hukum untuk mendapatkan perlindungan hukum mengenai sesuatu hal baik yang bersifat materiil maupun immateriil berkaitan dengan masalah atau perkara yang dihadapi.

Dalam Lampiran Surat Keputusan Kapolri No. Pol : SKEP/1205/IX/ 2000 mengatakan bahwa :

"Perkara pidana adalah setiap perbuatan atau peristiwa yang diancam hukuman sebagai kejahatan atau pelanggaran baik yang disebut dalam Kitab Undang-Undang Hukum Pidana (KUHP) maupun Peraturan Perundang-undangan lainnya."

\section{Penyelidikan dan Penyidikan} bahwa :

Berdasarkan pasal 1 butir 5 Kitab Undang-Undang Hukum Acara Pidana (KUHAP) berbunyi

"Penyelidikan adalah serangkaian tindakan penyelidik untuk mencari dan menemukan suatu peristiwa yang diduga sebagai tindak pidana guna menentukan dapat atau tidaknya dilakukan penyidikan menurut cara yang diatur dalam undang-undang ini”. berbunyi :

Sedangkan dalam pasal 1 butir 2 Kitab Undang-Undang Hukum Acara Pidana (KUHAP)

"Penyidikan adalah serangkaian tindakan penyelidik dalam hal menurut cara yang diatur dalam undang-undang ini untuk mencari serta mengumpulkan bukti yang dengan bukti ini membuat terang tentang tindak pidana yang terjadi guna menemukan tersangkanya".

Kedua istilah tersebut di atas mempunyai pengertian yang berbeda, meskipun tindakantindakan penyelidikan dan penyidikan tidak dapat dipisahkan bahkan merupakan suatu kelanjutan dan penyelidikan hanyalah salah satu cara atau metode daripada penyidikan. Dari kedua batasan tentang penyelidikan maupun penyidikan tersebut, maka diperoleh satu perbedaan obyek ataupun sasaran yang hendak dicapai.

Dalam Bab I pasal 1 butir 4 Kitab Undang-Undang Hukum Acara Pidana (KUHAP), diatur tentang pengertian penyelidik yang selengkapnya berbunyi sebagai berikut :

"Penyelidik adalah pejabat polisi Negara Republik Indonesia yang diberi wewenang oleh Undang-Undang ini untuk melakukan penyelidikan".

Sedangkan dalam pasal 1 butir 1 Kitab Undang-Undang Hukum Acara Pidana (KUHAP) mengatur tentang penyidik yang berbunyi sebagai berikut :

"Penyidik adalah pejabat polisi Negara Republik Indonesia atau pejabat negeri sipil tertentu yang diberi wewenang khusus oleh Undang-Undang untuk melakukan penyidikan”. 
Motivasi penyelidikan memberikan perlindungan Hak Asasi Manusia (HAM) dengan pembatasan yang ketat terhadap penggunaan upaya hukum. Dalam HIR istilah penyelidikan tidak didapatkan, yang ada pengusutan (opspring) yang berupa pemeriksaan permulaan oleh pejabat yang berwenang setelah mereka mengetahui atau melanggar telah terjadi suatu pelanggaran hukum.

Penyelidik dalam melaksanakan wewenangnya bukan didasarkan atas kekuasan akan tetapi pada tanggung jawab. Hal ini sesuai dengan pasal 5 Kitab Undang-Undang Hukum Acara Pidana (KUHAP) mengenai wewenang penyelidik adalah :

1. Karena kewajibannya mempunyai wewenang :

a. Menerima laporan atau pengaduan dari seseorag tentang adanya tindak pidana.

b. Mencari keterangan dan barang bukti.

c. Menyuruh berhenti seseorang yang dicurigai dan menanyakan serta memeriksa tanda pengenal diri.

d. Mengadakan tindakan lain menurut hukum yang bertanggung jawab.

2. Atas perintah penyidik dapat melakukan tindakan berupa :

a. Penangkapan, larangan meninggalkan tempat, penggeledahan dan penyitaan.

b. Pemeriksaan dan penyitaan surat-surat.

c. Mengambil sidik jari dan memotret seseorang.

d. Membawa dan menghadapkan seseorang pada penyidik.

Wewenang penyelidik tersebut di atas menurut angka 1 huruf d yaitu mengadakan tindakan lain menurut hukum yang bertanggung jawab, maka yang dimaksud tindakan lain adalah tindakan dari penyelidik untuk kepentingan penyelidikan dengan syarat tidak bertentangan dengan suatu aturan hukum, selaras dengan kewajiban hukum yang mengharuskan dilaksanakannya tindakan jabatan, tindakan itu harus patut dan masuk akal serta termasuk dalam lingkungan jabatannya, atas pertimbangan yang layak berdasarkan keadaan memaksa serta menghormati Hak Asasi Manusia (HAM).Pelaksanaan wewenang penyidik tersebut diatur lebih lanjut dalam pasal 102 Kitab Undangundang Hukum Acara Pidana (KUHAP).

Wewenang penyidik tersebut di atas berkaitan dengan pasal 106 Kitab Undang-Undang Hukum Acara Pidana (KUHAP) yang berbunyi :

"Penyidik yang mengetahui, menerima laporan atau pengaduan tentang terjadinya suatu peristiwa yang patut diduga merupakan tindak pidana wajib segera melakukan tindakan penyidikan yang diperlukan”.

Dari batasan penyelidik dan penyidik berdasarkan uraian tersebut di atas, maka penulis dapat menyimpulkan bahwa yang dimaksud dengan penyelidik adalah setiap pejabat polisi Negara Republik Indonesia mulai dari pangkat Prajurit Dua sampai dengan pangkat Jendral dapat bertindak sebagai penyelidik.

Sedangkan pejabat polisi Negara Republik Indonesia tertentu sekurang-kurangnya berpangkat Letnan Dua atau Kepala Sektor yang berpangkat Bintara dibawah Pembantu Letnan Dua karena jabatannya dapat bertindak sebagai penyidik pembantu.

\section{Penangkapan dan Penahanan}

Pengertian penangkapan berdasarkan ketentuan yang terdapat pada pasal 1 butir 20 Kitab Undang-Undang Hukum Acara Pidana (KUHAP) berbunyi :

"Penangkapan adalah suatu tindakan penyidik berupa pengekangan sementara waktu kebebasan tersangka atau terdakwa apabila terdapat cukup bukti guna kepentingan penyidikan atau penuntutan dan atau peradilan dalam hal serta menurut cara yang diatur dalam UndangUndang ini”.

Dari pengertian tersebut di atas dapat dimengerti bahwa apabila penyidik atau penyidik pembantu ataupun penyelidik atas perintah penyidik akan melakukan penangkapan terhadap seseorang yang disangka atau didakwa telah melakukan tindak pidana harus mendasarkan penangkapan itu kepada :

a. Adanya bukti permulaan yang cukup.

b. Semata-mata guna kepentingan, penuntutan dan peradilan.

c. Berdasar tata cara yang diatur dalam Kitab Undang-Undang Hukum Acara Pidana (KUHAP). 
Atas dasar ketentuan tersebut, baik penyidik ataupun penyidik pembantu tidak dibenarkan melakukan penangkapan terhadap seseorang dengan semena-mena atau tanpa alasan yang jelas dan bertentangan dengan Undang-Undang yang mengatur dalam hal tersebut. berbunyi :

Sedangkan dalam pasal 1 butir 21 yang mengatur tentang pengertian penahanan yang

"Penahanan adalah penempatan tersangka atau terdakwa di tempat tertentu oleh penyidik, atau penuntut umum atau Hakim dengan penempatannya, dalam hal serta menurut cara yang diatur dalam Undang-Undang ini”.

Jadi jelaslah bahwa penahanan sebagaimana tersebut di atas dapatlah dimengerti, bahwa penahanan itu adalah penempatan tersangka atau terdakwa di tempat tertentu yang dilakukan oleh penyidik, penuntut umum atau Hakim untuk kepentingan penyidikan, penuntutan dan peradilan berdasarkan tata cara yang diatur dengan Undang-Undang.

Martiman Pradjahamidjaja mengatakan bahwa penahanan harus berdasarkan hukum dan keperluan. (1988:30) "Dasar menurut hukum adalah harus ada dugaan keras berdasarkan bukti yang cukup bahwa orang itu telah melakukan tindak pidana dan bahwa terhadap tindak pidana itu diancam dengan hukuman penjara paling lama lima tahun atau lebih, atau suatu tindak pidana tertentu yang ditentukan oleh Undang-Undang meskipun ancaman hukumannya kurang dari lima tahun".

Dasar menurut hukum saja tidak cukup untuk menahan seseorang, karena itu dilengkapi dengan dasar menurut keperluan yaitu dengan adanya kekhawatiran bahwa tersangka atau terdakwa akan melarikan diri atau merusak/menghilangkan barang bukti atau akan mengulangi tindak pidana tersebut. Sifat alasan menurut keperluan adalah alternatif, artinya apabila terdapat salah satu dari ketiga pernyataan tersebut di atas maka sudah dapat dilakukan penahanan.

Apabila seseorang ditangkap atau ditahan dasar hukum atau dasar keperluan serta ia berpendapat "bahwa penangkapan atau penahannya tidak sah yaitu tidak memenuhi persyaratan perundang-undangan, maka ia dapat meminta pemeriksaan dan putusan oleh Hakim tentang sahnya penangkapan atas dirinya tersebut, serta berhak minta ganti rugi”. Upaya ini dilakukan pada tingkat penyidikan dan penuntutan dengan proses pra peradilan. (Martiman Pradjahamidjaja,1988:44)

Dalam hal tertangkap dengan penangkapan dilakukan tanpa surat perintah, dengan ketentuan bahwa penangkapan harus segera menyerahkan tertangkap bersama barang bukti yang ada kepada penyidik pembantu yang terdekat.

Setelah diketahui tentang kewenangan serta pelaksanaan tugas penangkapan, maka penulis menguraikan tentang hak-hak tersangka yang dikenai penangkapan. Untuk menjamin hak, harkat dan martabat seseorang tersangka atau pelaku tindak pidana yang dikenakan penangkapan.

Oleh Undang-Undang kepada tersangka yang dikenakan penangkapan diberi hak untuk :

a. Menanyakan surat tugas.

b. Menanyakan surat perintah penangkapan

Jadi jelaslah disini bahwa kepada tersangka atau pelaku tindak pidana oleh Undang-Undang tetap dilindungi hak-haknya. Hak tersebut di atas dimaksudkan pula untuk menghindari kesalahan dalam penangkapan terhadap tersangka serta menghindari tindakan sewenang-wenang dari aparat penegak hukum tanpa memperhatikan peraturan yang ada.

Sehubungan dengan hal tersebut di atas, tersangka diperkenankan pula untuk membaca dengan seksama tentang surat perintah penangkapan yang memuat identitasnya.

\section{Hak-Hak Tersangka Waktu Penahanan}

Dalam proses perkara pidana pada dasarnya ada tiga instasi penegak hukum yang berwenang dalam menyelesaikan perkara pidana antara lain Kepolisian Negara Republik Indonesia selaku penyidik, Jaksa selaku penuntut umum dan Hakim yang memaksa dan memutuskan hukumannya.

Dalam pada itu seseorang yang diperiksa di tingkat penyidikan (opsporing) karena diduga telah melakukan tindak pidana, dalam kedudukannya yang demikian itu ia berstatus sebagai tersangka akan tetapi bilamana seseorang tersebut berada dalam proses penuntutan oleh kejaksaan (nasporing) sampai pada taraf pemeriksaan di pengadilan tetapi belum sampai vonis Hakim yang memperoleh kekuatan hukum yang tetap, maka ia statusnya sebagai terdakwa.

Hal ini sesuai dengan adagium atau asas praduga tak bersalah yang mengandung pengertian belum dianggap telah bersalah sebelum adanya putusan Hakim yang memperoleh kekuatan hukum tetap. Juga untuk menghindari adanya tindakan sewenang-wenang dari pejabat penegak hukum serta 
menghindari adanya tindakan main hakim sendiri, ini masih sering terjadi didalam kehidupan masyarakat sehari-hari tanpa melalui proses persidangan sesuai dengan prosedur hukum yang berlaku.

Selama dalam penahanan, penyidik tidak menghalangi tersangka untuk menggunakan hakhaknya sesuai dengan pasal 50 sampai dengan pasal 68 Kitab Undang-Undang Hukum Acara Pidana (KUHAP) .

\section{Pelaksanaan Pemeriksaan Pendahuluan oleh Penyidik}

Pemeriksaan merupakan kegiatan untuk mendapatkan keterangan, kejelasan dan keidentikan tersangka dan atau saksi dan atau barang bukti maupun tentang unsur-unsur tindak pidana yang telah terjadi sehingga kedudukan atau peranan seseorang maupun barang bukti didalam tindak pidana tersebut menjadi jalas dan dituangkan didalam Berita Acara Pemeriksaan (BAP).

Yang berwenang melakukan pemeriksaan adalah penyidik atau penyidik pembantu, dimana pemeriksaan dilakukan atas dasar :

1. Laporan Polisi.

2. Laporan hasil penyelidikan yang dibuat oleh petugas atas perintah penyidik atau penyidik pembantu.

3. Berita Acara Pemeriksaan (BAP) di Tempat Kejadian Perkara (TKP), penangkapan, penahanan, penggeledahan dan penyitaan.

4. Petunjuk dari penuntut umum untuk melakukan pemeriksaan tambahan.

5. Dalam hal saksi/tersangka berada di luar wilayah hukum penyidik/ penyidik pembantu yang melakukan penyidikan, dapat meminta bantuan penyidik/penyidik pembantu dari kesatuan di mana saksi/ tersangka berada.

\section{Peranan Penasehat Hukum dalam Pemeriksaan Pendahuluan}

Sebelum dimulainya pemeriksaan, penyidik wajib memberitahukan hak tersangka untuk mendapatkan bantuan hukum atau dalam perkara tertentu sebagaimana dimaksud dalam pasal 56 Kitab Undang-Undang Hukum Acara Pidana (KUHAP) ia wajib didampingi penasehat hukum.

Menurut pasal 1 Keputusan Bersama Ketua Mahkamah Agung dan Menteri Kehakiman Republik Indonesia Nomor : KMA/805/SKB/VIII/1987 tentang Tata Cara Pengawasan, Pemidanaan dan Pembelaan Diri Penasehat Hukum, penasehat hukum adalah :

"Mereka yang memberikan bantuan atau nasehat hukum, baik yang bergabung atau tidak dalam suatu persekutuan penasehat hukum, baik sebagai mata pencaharian atau tidak, yang disebut sebagai pengacara/advokat atau pengacara praktek".

Menurut pasal 1 ayat (13) Kitab Undang-Undang Hukum Acara Pidana (KUHAP) penasehat hukum adalah :

"Seseorang yang memenuhi syarat yang ditentukan oleh atau berdasar Undang-Undang untuk memberi bantuan hukum".

Dalam perkara pidana, peranan penasehat hukum dalam pemeriksaan pendahuluan adalah :

1. Membantu mencari, menemukan dan menegakkan kebenaran dan keadilan.

2. Membantu memperlancar penyelesaian perkara dengan menjunjung tinggi Pancasila, hukum dan keadilan (pasal 37 Undang-Undang Nomor 14 Tahun 1970).

3. Menjaga dan membela hak-hak tersangka/terdakwa (pasal 54 Kitab Undang-Undang Hukum Acara Pidana).

Pada waktu penyidik/penyidik pembantu sedang melakukan pemeriksaan terhadap tersangka, penasehat hukum dapat mengikuti jalannya pemeriksaan dengan cara melihat dan mendengar pemeriksaan, kecuali dalam hal kejahatan terhadap keamanan negara, penasehat hukum tidak dapat mendengar pemeriksaan terhadap saksi (Surat Keputusan Kapolri tanggal 11 September 2000 No.Pol. Skep/1205/ IX/2000 tentang Petunjuk Pelaksanaan Proses Penyidikan Tindak Pidana).

\section{Proses Pemeriksaan Tersangka oleh Penyidik}

Adapun proses pemeriksaan tersangka oleh penyidik dapat sebagai berikut :

1. Pengawasan dan Pengendalian Penerima Laporan dan Penanganan Laporan Polisi

2. Pengawasan dan Pengendalian Kegiatan Penyelidikan Tindak Pidana

3. Pengawasan dan Pengendalian Kegiatan Penyidikan Tindak pidana.

4. Pengawasan dan Pengendalian Kegiatan Penyelesaian dan Penyerahan Perkara 


\section{Pengawasan dan Pengendalian Perkara pada Tahap Penuntutan \\ 6. Pengawasan dan Pengendalian Perkara pada Tahap Peradilan. \\ 7. Pengawasan dan Pengendalian Terhadap Tahanan}

\section{Kendala-Kendala pada Tahap Pemeriksaan.}

Langkah-langkah yang harus diambil pada saat memulai pemeriksaan penyidikan, penyidik perlu mengingat adanya kewajiban yang harus diperhatikan dan dilaksanakan sebelum ia memulai penyidikan dan pemeriksaan tersangka antara lain :

1. Pada saat penyidik telah memulai melakukan tindakan penyidikan terhadap suatu peristiwa yang diduga merupakan tindak pidana, penyidik memberitahukan hal itu kepada penuntut umum pada saat penyidik melakukan tindakan penyidikan misalnya telah mulai dilakukan penangkapan, pemanggilan, penggeledahan, penahanan, penyitaan dan sebagainya.

2. Sebelum mulai pemeriksaan penyidik wajib memberitahukan kepada tersangka tentang hakhaknya untuk mendapatkan bantuan hukum atau tersangka wajib didampingi oleh penasehat hukum.

Dengan memberikan hak-haknya kepada tersangka itu merupakan cara terpenting pada saat diminta keterangan oleh penyidik. Untuk pemeriksaan tersebut dilakukan satu atau dua orang penyidik dalam ruangan khusus.

\section{Faktor Teknis}

Adapun kendala-kendalanya adalah terdiri dari faktor teknis dan faktor non teknis.

Teknik penyidikan atau teknik kriminil yang baik dapat memberikan jawaban atas pertanyaanpertanyaan sehingga proses penyidikannya berjalan lancar. Secara keseluruhan dalam proses penyidikan ini faktor teknis sangat ditentukan meliputi bidang-bidang sebagai berikut :

a. Bidang taktik penyidikan

Taktik penyidikan juga disebut taktik kriminal yaitu pengetahuan yang mempelajari problemproblem taktik dalam bidang penyidikan perkara pidana, seorang penyidik harus bersemangat menyala dan cepat. Kecepatan adalah tuntutan taktik pertama bagi pemeriksaan perkara, tetapi hal ini tidak boleh mengurangkan taktik penyelesaian pemeriksaan teknis dari perkara selanjutnya.

Para penyidik perkara harus senantiasa menyadari problem-problem apa yang harus dipecahkan dalam penyidikan itu dan kesulitan-kesulitan apa yang mereka akan hadapi. Yang termasuk bidang taktik penyidikan antara lain :

1) Tindakan pertama ditempat kejadian perkara.

2) Ilmu jiwa kriminal, khusus yang digunakan dalam mendengar keterangan saksi-saksi dan tersangka.

3) Hubungan dengan spionase bermacam-macam informan.

4) Taktik penangkapan, penggeledahan badan, menggeledah rumah, konfrontasi dan menyamar.

5) Penuntutan.

6) Modus operandi (kebiasaan kerja para pelaku kejahatan).

7) Pengumuman tentang terjadinya tindak pidana.

8) Baik buruknya dalam memberikan hadiah dalam mencari kejahatan.

9) Gunanya banyak membaca buku-buku cerita detektif.

10) Pengertian tentang bahasa sandi para penjahat, tahayul, jimat, guna-guna dan lainnya..

b. Bidang teknis penyidikan

Teknis penyidikan atau disebut teknik kriminal yaitu mengajarkan tentang menjawab pertanyaan-pertanyaan dalam bidang penyidikan. Yang termasuk dalam teknik bidang penyidikan ini adalah mengenai mengetahui tentang materiil, alat-alat atau sarana teknis, menetapkan dan melihat barang-barang dan mengetahui teknis identifikasi dan sinyalemen.

Selanjutnya untuk mencari bekas-bekas dan mengambil kesimpulan dari berkas-berkas itu dapat pula menggunakan bantuan dari ilmu pengetahuan seperti ilmu pengobatan, ilmu kimia, daktiloskopi, mikrofotografi, tape recorder, lidector dan lain-lain. Dengan sarana-sarana teknis ini banyak bekas-bekas materiil dapat dilihat seperti sidik jari yang tidak terlihat oleh mata, maka dengan bantuan teknik (fotografi), mekanik (serbuk), dan kimia (yodium) dapat dilihat dengan jelas.

Dalam hubungannya dengan penyidikan, maka teknik tentang mencari bekas atau juga ilmu bekas yang dibagi atas dua golongan yaitu : 
1) Ilmu bekas atasan adalah bidang-bidang ahli tertentu seperti ahli kedokteran, kehakiman, ahli pemeriksaan surat-surat palsu, ahli daktiloskopi.

2) Ilmu bekas bawahan adalah meliputi ajaran tentang mencari, menetapkan, mengamankan, menyita dan mengirimkan berkas dalam tindakan pertama di Tempat Kejadian Perkara (TKP).

Dalam teknik penyidikan termasuk pula bagian teknik identifikasi, juga termasuk bantuan untuk menyimpan berbagai macam kumpulan data-data seperti kartotik, kumpulan sinyalemen, fotofoto register, modus operandi, rumus-rumus daktiloskopi. Untuk teknik penyidikan ini senantiasa harus diperhatikan supaya teknik penyidikan selalu mengikuti perkembangan hasil-hasil terbaru yang dicapai dalam pemeriksaan.

\section{Faktor Non Teknis}

Faktor non teknis juga sangat menentukan kelancaran dan keberhasilan penyelesaian proses penyidikan, juga mempengaruhi pada subyek atau penyidik yang disebut faktor internal pada obyek atau tersangka yang disebut faktor eksternal.

Faktor internal yang ada pada penyidikan adalah faktor dirasakan dan dialami langsung oleh penyidik dalam melaksanakan proses penyidikan tersangka. Faktor-faktor yang dimaksud meliputi bidang-bidang sebagai berikut :

a. Kemampuan memahami pengetahuan hukum perundang-undangan

Dimaksudkan guna kelancaran dan suksesnya menjalankan tugas kepolisian yaitu dalam melaksanakan tugas-tugas penyidikan. Pengetahuan hukum perundang-undangan yang mendalam tentang segala sesuatu yang ada hubungannya dengan penyidikan. Pengetahuan hukum antara lain meliputi hukum pidana, hukum acara pidana, sosiologi kriminologi, kriminalistik serta pengetahuan lainnya.

b. Keberanian

Keberanian merupakan syarat mutlak bagi seorang penyidik yang dicita-citakan khususnya bagi Polri yang ditugaskan sebagai penyidik atau Reserse kriminal. Faktor keberanian disini dimaksudkan adalah sebagai penyidik harus bersikap tegas, trampil, waspada dan mahir dalam pembelaan diri.

c. Kewajiban

Dapat menunjang dalam pelaksanaan teknis penyidikan, di mana dalam proses pemeriksaan terhadap tersangka maka dalam hal ini sikap penyidik dalam melakukan pemeriksaan harus penuh inisiatif dalam penilaian, mengetahui strategi maupun sasaran yang dituju, mengatur persiapanpersiapan dan santun serta dan mudah beradaptasi.

d. Faktor komunikasi

Dapat mempengaruhi pelaksanaan penyidikan. Dalam hal ini pemeriksaan yang dilakukan oleh penyidik harus menggunakan bahasa yang dimengerti oleh kepentingan penyidikan.

Faktor eksternal ini adalah faktor-faktor yang ada dipihak obyek yaitu dipihak tersangka itu sendiri. Meskipun faktor-faktor teknis dan internal baik dan dipertimbangkan dengan matang, maka dalam hal ini proses penyidikan kurang begitu lancar dan hasilnyapun belum sesuai dengan tujuan penyidikan itu sendiri, maka faktor eksternal ini sangat penting dan perlu mendapatkan perhatian.

Yang perlu mendapat perhatian pada faktor eksternal ini meliputi hal-hal sebagai berikut :

a. Keberadaan tersangka

Langkah pertama yang dilakukan penyidik dalam pemeriksaan adalah memanggil atau menghadapkan tersangka. Sebagaimana yang diatur dalam pasal 112 Kitab Undang-Undang Hukum Acara Pidana (KUHAP) yaitu penyidik melakukan pemeriksaan dengan menyebutkan alasan pemanggilan secara jelas, dan berwenang memanggil tersangka ini merupakan salah satu faktor yang sangat menunjang bagi kelancaran penyidikan.

b. Kesehatan tersangka

Untuk kepentingan pemeriksaan agar supaya berjalan dengan lancar, maka kesehatan tersangka harus diperhatikan. Apabila tersangka terganggu/sakit, maka pemeriksaan akan mengalami kesulitan. Oleh karena itu kesehatan tersangka harus diperhatikan.

c. Kecemasan tersangka

Kecemasan daripada diri sendiri tersangka dapat dilihat pada keringat dingin, pucat atau gemetar dan sebagainya. Jika kecemasan tersangka dapat dimanfaatkan, maka pintu pengakuan segera terbuka, tetapi jika kecemasan itu semakin dipertebal oleh sikap dan ucapan-ucapan pemeriksa yang 
kurang pengalaman menghadapinya, bahkan akan merupakan tembok tebal yang hendak menutup kebenaran atau sekurang-kurangnya mempersulit keadaan.

Dalam menghadapi tersangka yang cemas, pemeriksa harus dapat memulihkan atau mengembangkan keadaan jiwanya menjadi stabil kembali, sehingga tersangka dalam menghadapi pemeriksaan tidak timbul rasa takut atau cemas..

d. Keadaan tersangka

Keadaan pada diri tersangka ini tidak lain dalam hal-hal yang melatar belakangi diri tersangka yang meliputi antara lain : pendidikan dan kepandaian, suku, agama, bahasa dan usianya. Demikian pula faktor ekonomi dapat mempengaruhi kelancaran dalam proses pemeriksaan terhadap tersangka. Penyidik dalam menghadapi tersangka dengan keadaan yang berbeda akan mengalami kesulitan, jika hanya mempergunakan model teknik dan teknis penyidikan.

e. Kelengkapan bukti-bukti pemeriksaan

Untuk kepentingan pemeriksaan perkara pidana yang dilakukan oleh tersangka, maka dalam hal ini penyidik mengumpulkan dan mencatat sebanyak-banyak mungkin keterangan-keterangannya, data-data atau fakta yang benar mengenai tindak pidana yang telah terjadi. Pada umumnya untuk mencari bukti itu secara sistematis harus dilalui tiga proses yaitu :

1) Informasi adalah penyidik mengumpulkan keterangan serta bukti, terutama dapat diperoleh dengan mengolah Tempat Kejadian Perkara (TKP) secara sistematis.

2) Interogasi adalah memeriksa atau mendengar keterangan orang yang dicurigai dan juga saksi-saksi yang dapat diperoleh di Tempat Kejadian Perkara (TKP).

3) Inatrumentarium adalah pemakaian alat-alat teknik untuk pemeriksaan atau penyidikan perkara seperti photografi, mikroskop dan lainnya yang ada di Tempat Kejadian Perkara (TKP) atau juga di laboratorium.

Setelah mendapatkan keterangan dan bukti-bukti serta data yang lengkap, maka akan menghasilkan identitas tersangka. Dengan demikian faktor kelengkapan bukti-bukti ini mempengaruhi kelancaran proses penyidikan perkara pidana. Disamping itu juga faktor kelengkapan bukti-bukti ini menentukan, apakah tersangka bersalah atau tidak.

Dalam pemeriksaan pendahuluan, terutama dalam meminta keterangan/informasi terhadap tersangka, penyidik harus menguasai dan dapat menerapkan pengetahuan psikologi. Psikologi sangat besar peranannya dalam proses ini, karena psikologi lebih melihat latar belakang tingkah laku perbuatan individu yang diperiksa.

Dengan menerapkan bidang psikologi tersebut, seorang penyidik dapat mempelajari dan mengenal lebih dalam tentang apa dan siapa tersangka itu, bagaimana watak dan kepribadiannya, sifatsifatnya sehingga dapat ditentukan cara pendekatan yang lebih akrab dan intim.

Semakin mengenal pribadi tersangka, semakin akrab dan lancar komunikasi antara penyidik dan tersangka. Keakraban tersebut dapat membantu penyidik mengumpulkan keterangan tersangka sebagai salah satu bahan untuk pembuktian. Pendekatan tersebut juga dapat diterapkan untuk mengatasi bila/seandainya tersangka mempunyai rasa enggan untuk menjawab atau memberikan keterangan.

Yang masuk bidang taktik penyidikan antara lain :

a. Menghindari sikap yang dapat menimbulkan kesan pada tersangka bahwa pemeriksaan hendak berusaha untuk memperoleh pengakuan atau hendak mencari kesalahan.

b. Dalam pemeriksaan pendahuluan, pemeriksa menjauhi pensil kertas yang biasanya dipergunakan sebagai alat-alat untuk melakukan pencatatan, yang dirasakan oleh tersangka sebagai suasana yang tidak tegang.

c. Dalam mengucapkan istilah-istilah seperti membunuh, mencuri itu tidak dipergunakan periksa tetapi penyidik menggunakan istilah seperti mengambil atau katakanlah sebenarnya, jika yang diperiksa kelihatan berbohong, maka tidak menggunakan kata bohong tetapi menggunakan kalimat 'kau belum menjelaskan keseluruhannya'.

d. Pemeriksa dan yang diperiksa dapat duduk saling berhadapan dan berdekatan kira-kira 27 inchi dengan menggunakan kursi yang mempunyai tangan dan sandaran.

e. Selama pemeriksaan dilakukan, pemeriksa tidak mondar-mandir di bilik sehingga dapat menggangg pikiran yang diperiksa dalam hal mengingat sesuatu.

f. Selama pemeriksaan dilakukan penyidik menggunakan bahasa yang dimengerti oleh tersangka. 
g. Pemeriksa berusaha untuk tetap menghargai pribadi orang yang diperiksa, betatapun perbuatannya menyakitkan.

h. Apabila tersangka itu berbohong, maka penyidik menunjukkan hal-hal yang dapat menimbulkan kesan kepada yang diperiksa, bahwa pemeriksa tahu keadaan sebenarnya yang belum diceritakan oleh tersangka.

i. Dalam pemeriksaan, tersangka tidak dikenakan belenggu selama kehadirannya.

j. Memandang orang yang diperiksa adalah sebagai manusia dengan sifat-sifat kemanusiaannya.

k. Dalam pemeriksaan, penyidik lebih banyak menggunakan kata-kata yang baik sehingga tidak ada rasa takut.

1. Waktu pemeriksaan berlangsung, jangan sampai ada dinding pemisah antara penyidik dengan tersangka.

m. Apabila dalam pemeriksaan itu tersangka mengingkari maka penyidik mendekati secara baik-baik. Pemeriksaan harus mampu memberikan sedikit tekanan, simpati yang sesuai dengan tujuannya. Penyidikan akan dikatakan berhasil apabila penyidik itu mengabdikan diri sepenuhnya untuk tugas. Untuk itu ada ketentuan dasar yang harus diperhatikan ketika dalam menyusun dan membuat pertanyaan yaitu :

a. Pertanyaan seharusnya tidak kompleks, sebab mereka akan kesulitan untuk memahaminya.

b. Pertanyaan seharusnya pendek dan dibatasi hanya satu tapi harus jelas dan mudah dimengerti.

c. Pertanyaan utama seharusnya dihindari dulu untuk memberikan kemudahan proses pertanyaan.

d. Perkataan rumit jangan digunakan dalam pemeriksaan.

e. Pendekatan dan pertanyaan yang akan digunakan harus dibedakan sesuai dengan tipe tersangka tersebut.

Dengan mengikuti aturan-aturan tersebut antara penyidik dan tersangka akan lebih mudah untuk saling mengerti apa yang dibicarakan. Pertanyaan terhadap tersangka yang jelas salah dengan pertanyaan terhadap tersangka yang belum jelas bersalah, maka dituntut menggunakan pendekatan lain. Dalam menghadapi tersangka yang kesalahannya dapat dipastikan, maka pemeriksaan dilakukan untuk memperoleh pengakuan tersangka dari pihak tersangka serta menyesuaikan pembuktian yang telah dikumpulkan.

Adapun dalam menghadapi tersangka yang kesalahannya belum pasti, maka hal ini ada 3 (tiga) cara pendekatan antara lain :

a. Dalam mengemukakan pertanyaan sejak permulaan pemeriksaan, hendaklah dianggap bahwa orang itu telah melakukan hal-hal yang menyebabkan ia diperiksa.

b. Pemeriksaan dapat pula dengan cara menentukan suatu anggapan bahwa yang diperiksa adalah tidak bersalah.

c. Pemeriksaan dapat pula menempatkan diri secara netral, hemat dengan pertanyaan yang pada akhirnya memberikan kesimpulan kepada pemeriksa apabila yang diperiksa bersalah atau tidak.

Dengan demikian penyidik dapat menggunakan teknik yang berbeda untuk pemeriksaan tersangka yang sudah jelas bersalah dengan tersangka yang belum pasti bersalah, maka dalam percakapannya itu disaksikan oleh petugas lain yang memelihara kesejahteraan tersangka.

\subsection{Pemeriksaan dalam Persidangan oleh Hakim}

Pemeriksaan dalam sidang pengadilan bertujuan meneliti dan menyaring apakah suatu tindak pidana itu benar atau tidak, apakah bukti-bukti yang dimajukan itu sah atau tidak, apakah pasal dalam Kitab Undang-Undang Hukum Pidana (KUHP) yang dilanggar itu sesuai perumusannya dengan tindakan pidana yang telah terjadi itu.

Pemeriksaan di muka pengadilan bersifat aqusatoir yang berarti si terdakwa mempunyai kedudukan sebagai pihak yang sederajat menghadapi pihak lawannya, yaitu penuntut umum, seolaholah kedua belah pihak itu sedang bersengketa di muka Hakim, yang nanti akan memutuskan persengketaan itu. Pemeriksaan di muka sidang pengadilan dilakukan secara terbuka untuk umum, kecuali kalau peraturan menentukan lain misalnya dalam hal pemeriksaan kejahatan kesusilaan dan lain-lain.

Setelah semua surat pemeriksaan pendahuluan selesai, Kepala Kejaksaan Negeri akan menyerahkan surat-surat itu serta bukti-buktinya dalam perkara yang bersangkutan kepada Ketua Pengadilan Negeri yang berwenang, dengan memintakan supaya perkara diserahkan kepada pengadilan. 
Setelah Ketua ataupun Hakim telah mempelajari berkas pemeriksaan pendahuluan itu dan menganggapnya cukup, maka ia menentukan suatu haris sidang dengan memerintahkan kepada Jaksa untuk memanggil terdakwa dan saksi-saksi untuk menghadap ke muka sidang.

Pada waktu menerima panggilan si terdakwa akan diberikan suatu salinan dari surat dakwaan yang dikeluarkan oleh Hakim Pengadilan Negeri yang disalin dari tuduhan yang telah diajukan oleh Jaksa. Dalam surat tuduhan termuat suatu penguraian tentang perbuatan-perbuatan yang telah dilakukan oleh si terdakwa yang dipandang sebagai pelanggaran Kitab Undang-Undang Hukum Acara Pidana (KUHAP), dengan diterangkan keadaan-keadaan dalam mana perbuatan itu dilakukan, dengan menyebutkan pasal-pasal Undang-Undang yang dilanggar.

Setelah pemeriksaan selesai penuntut umum (Jaksa) membacakan tuntutannya (requisitoir) dan menyerahkan tuntutan itu kepada Hakim. Dan setelah Hakim memperoleh keyakinan perkaraperkara tersebut, maka ia akan mempertimbangkan hukuman apa yang akan diajukannya.

Menurut Kitab Undang-Undang Hukum Acara Pidana (KUHAP) keputusan Hakim (vonis) dapat berupa :

1. Penjatuhan hukuman (veroordeling)

Dalam hal ini oleh Hakim diputuskan bahwa terdakwa terang bersalah telah melakukan peristiwa pidana yang dituduhkan kepadanya (pasal 193 ayat (1) Kitab Undang-Undang Hukum Acara Pidana).

2. Pembebasan dari penuntutan hukuman (ontslag van rechtsvervolging)

Dalam hal ini Hakim memutuskan bahwa peristiwa yang dituduhkan kepada terdakwa itu dibuktikan dengan cukup terang, akan tetapi peristiwa itu ternyata bukan peristiwa pidana, atau terdakwanya kedapatan tidak dapat dihukum, karena tidak dapat dipertanggungjawabkan atas perbuatannya itu (pasal 191 ayat (2) Kitab Undang-Undang Hukum Acara Pidana).

3. Putusan bebas (vrijspraak)

Putusan ini berarti bahwa kesalahan terdakwa atas peristiwa yang dituduhkan kepadanya tidak cukup buktinya (pasal 191 ayat (1) Kitab Undang-Undang Hukum Acara Pidana).

\section{Kesimpulan}

Hak tersangka yang dilindungi saat memberikan keterangan yaitu berhak segera mendapat pemeriksaan oleh penyidik,berhak memberikan keterangan secara bebas kepada penyidik, berkak mendapat bantuan juru bahas,berhak mendapat bantuan hukum dari seseorang atau penasehat hukum pada setiap tingkat pemeriksaan, berhak memilih penasehat hukumnya,berhak menerima kunjungan dokter pribadi,berhak mengajukan saksi yang menguntungkan bagi dirinya,dan hak -hak lainnya.

\section{Saran-saran}

1. Polri hendaknya sebagai lembaga yang mandiri dan independen dari segala bentuk intervensi, sehingga ia bisa bebas mengembangkan kemandiriannya dan keprofesionalismenya dengan didukung oleh fasilitas yang ada. Termasuk dalam penyidikan Polisi tidak akan terburu-buru untuk mendapatkan keterangan dengan cara yang tidak manusiawi atau kekerasan.

2. Proses penyidikan perkara pidana sebaiknya dilakukan dengan taktik dan teknis penyidikan yang baik dan teratur, serta dilakaukan secara terorganisasi.

\section{DAFTAR PUSTAKA}

Adji Oemar Seno, KUHAP Sekarang, Erlangga, Jakarta, 2002.

Bawengan GW, Penyidikan Perkara Pidana dan Teknik Interogasi, Cetakan ke-3, PT. Pradnya Paramita, Jakarta, 2001.

Hamzah Andi, Hukum Acara Pidana Indonesia, Arikha Media Cipta, Jakarta, 1993.

Hanijito Rony, Metode Penelitian Hukum, Ghalia Indonesia, Jakarta, 2006.

Harahap M. Yahya, Pembahasan Permasalahan dan Penerapan KUHAP, Jilid I, Pustaka Kartini, Jakarta, 2000.

Kansil CST, Pengantar Hukum Indonesia dan Tata Hukum Indonesia, Cetakan ke-8, Balai Pustaka, Jakarta, 1989. 
Kusnardi Moh dan Ibrahim Harmaily, Hukum Tata Negara Indonesia, Cetakan ke-5, PT. Sastra Hudaya, Jakarta, 1983.

Prakoso Joko, Peranan Psikologi dalam Pemeriksaan Tersangka pada Tahap Penyidikan, Ghalia Indonesia, Jakarta, 1986.

---------, Upaya Hukum yang Diatur didalam KUHAP, Aksara Persada Indonesia, Jakarta, 1997.

Projohamidjojo Martiman, Pembahasan Hukum Acara Pidana dalam Teori dan Praktek, PT. Pradnya Paramita, Jakarta, 1988.

Suriatmodjo Soetomo, Penangkapan dan Penahanan di Indonesia, PT. Pradya Paramita, Jakarta, 2004.

Kitab Undang-Undang Hukum Acara Pidana

Bahan Pokok Penyuluhan Hukum, Undang-Undang Hukum Acara Pidana, Dep. Kehakiman RI, Jakarta, 1998.

Lampiran Surat Keputusan Kapolri Tanggal 11 September 2000 No.Pol. Skep/1205/2000 tentang Proses Penyidikan Tindak Pidana

Petunjuk Pelaksanaan dan Petunjuk Teknis tentang Penyidikan, Mabes Polri, Jakarta, 1983. 